\title{
Validation of microwave-assisted sample extraction-high performance liquid chromatography (HPLC) method for quantitative analysis of hydrolysed amino acids in aquatic biological samples
}

\author{
G.D.T.M. Jayasinghe and B.K.K.K. Jinadasa* \\ Analytical Chemistry Laboratory, National Aquatic Resources Research \& Development \\ Agency (NARA), Crow Island, Colombo-15, Sri Lanka \\ * Correspondence (jinadasa76@gmail.com) \\ iD http://orcid.org/0000-0002-0465-6950
}

\begin{abstract}
A sensitive and widely applicable High-Performance Liquid Chromatography (HPLC) with fluorescence detector (FLD) method for determination hydrolysed amino acids in fish and aquatic products was developed and validated through study. The method involved a microwave-assisted sample extraction and protein hydrolysed with the hydrochloric acid and propionic acid. The separation was performed by Shim-pack HR-ODS column with a gradient mobile phase. The total separation time was $25 \mathrm{~min}$ per run. The method showed satisfactory linearity, repeatability, accuracy, and limit of detection for 21 amino acids with the $1-100 \mathrm{mg} / \mathrm{L}$ calibration range based on $10 \mu \mathrm{L}$ injection. The fish, fish feed, canned fish and seaweeds samples were analysed successfully by using this developed method.
\end{abstract}

Keywords: Amino acids, fish, HPLC-FLD, method validation

\section{INTRODUCTION}

Amino acids play a major role in cellular metabolism, as a structural unit for protein, energy source, regulating gene expression act as a neurotransmitter, participate in the modulation of protein synthesis, biosynthesis of trace amines, lipid transport (Lorenzo et al. 2013; Yanting et al. 2018; Min et al. 2017) and biosynthesis of vitamins (Mudiam and Ratnasekhar 2013). Some amino acids such as aspartic acid (Asp), glutamic acid (Glu), $\gamma$ aminobutyric acid (GABA), and taurine (Tau) act as a neurotransmitter (Yanting et al. 2018) while some of them such as glutamine (Gln) and glycine (Gly) inhibitory signals (Lorenzo et al. 2013).

Determination of amino acids in biological samples such as fish and the aquatic product is very important for modern fisheries, aquaculture, and the human health sector. Today aquaculture achieved this development through proper farm management, genetics, disease control and a better understanding of nutrient requirements of farmed animals, ingredient processing and feed manufacturing (Nunes et al. 2014). Due to inadequate consumption of quality protein through human diets leads to protein-calorie malnutrition, Kwashiorkor, Marasmus (Bimal et al. 2014), type II diabetics, renal disease and carcinogenesis (Yanting et al. 2018).

Quantitative analysis of amino acid profile in fish and fisheries products is an important as well as the challenge, in food analysis laboratory, because it do not have a chromophore, high hydrophilic and polarity property and some of these amino acids can be lost during the sample treatment (Choi et al. 2017). Most of the amino acids show poor solubility near the Iso-electric point when separation. The combination of the above factors is critical to the separation and quantification of amino acids in different food matrices.

There are several methods for amino acids analysis in fish and aquatic samples. The classical amino acids analysis method is consisting two steps, (i) hydrolysis, which helps to liberate analyte from the substrate and (ii) chromatographic analysis for the qualitatively and quantitatively analysis of the analyte. Several factors affect to hydrolysis step such as temperature, time, hydrolysis agent, additives (Fountoulakis and Lahm 1998), sample matrices and reagents (Dai et al. 2014). There are several types of hydrolysis process involve, known as acid hydrolysis, alkyl hydrolysis, enzyme hydrolysis, polyacrylamide gel hydrolysis and 
cleavage hydrolysis (Fountoulakis and Lahm 1998).

The common hydrolysis type expresses the many disadvantages; when using $6 \mathrm{M} \mathrm{HCl}$, the Tryptophan (Trp) destroyed completely. On the other hand, there is little loss of Trp when protein hydrolysed with alkaline such as $\mathrm{NaOH}$. But Arginine (Arg), Asparagine (Asn), Cysteine (Cys), Glutamine (Gln), Methionine (Met), Serine (Ser) and Threonine (Thr) are significantly decomposed in such processes (Dai et al. 2014). The traditional acid hydrolyses method generally performed with $6 \mathrm{~N} \mathrm{HCl}$ at $110^{\circ} \mathrm{C}$ for $24 \mathrm{hrs}$ (Damm et al. 2010; AfiuniZadeh et al. 2011). The microwave assisted hydrolysed method to develop recently as a useful tool for a range of protein sample preparation for proteome analysis (Chen et al. 2014; Wang and Li 2010). This method helps to reduce hydrolysing time significantly as a major advantage. Nevertheless, this technique helps to recover higher yield of residues and reproducibility (Yu et al. 1988).

The High-Performance Liquid Chromatography (HPLC) combine with the pre-column derivatizing technique provides advantages of amino acids analysis such as wide acceptance and ability to use different derivatization reagents (Jajić et al. 2013). o-phthaldialdehyde (OPA) is one of the common derivatizing agent for the primary amino acids at room temperature (Li et al. 2011). 9-fluorenylmethylchloroformate (FMOC) used as a derivatizing agent for secondary amino acids such as hydroxyproline, sarcosine, and proline (Einarsson 1985). Through the chromatographic analysis part involving ultraviolet, fluorescent, electrochemical and mass spectrometry detection are used (Yanting et al. 2018).

There are few references available for microwave assisted sample hydrolysing method for determination of amino acids in fish and aquatic products. The objective of this work is to optimize and validate a robust and easy precolumn derivatizing, HPLC method with a microwave-assisted sample extraction procedure for the analysis of amino acids in fish, fishery products, and aquatic resources as well as its application to real sample analysis.

\section{MATERIALS AND METHODS}

\section{Chemicals and reagents}

The number of 21, L-Amino Acids (1 g each, HPLC), L-Glycine, L-Alanine, L-Arginine Hydrochloride, L-Asparagine, L-Aspartic Acid, L-Cysteine hydrochloride, L-Glutamic Acid, LGlutamine, L-Histidine Hydrochloride, LIsoleucine, L-Leucine, L-Lysine Hydrochloride, L-Methionine, L-Phenyl alanine, L-Proline, LHydroxyproline, L-Serine, L-Threonine, LTryptophan, L-Tyrosine, L-Valine were from Sigma Aldrich, Germany. Boric acid, Mercaptopropionic acid (MPA), o-phthalalaldehyde (OPA), 9- fluorenylmethyl-chloroformate (FMOC), Propionic acid, Hydrochloric acid $(\mathrm{HCl})$, Sodium Hydroxide $(\mathrm{NaOH})$, Methanol and Acetonitrile were purchased from Sigma (USA). All chemicals and reagents were in AR or HPLC grade (High purity, $\geq 99 \%$ ).

\section{Sample collection and preparation}

The fresh fish (Lutjanus sp.), canned fish (yellowfin tuna), fish feed and seaweed (Sargassum sp.) were used for the method validation. Samples were homogenised using a domestic blender to obtain an equal portion. Then, weight $50.0 \mathrm{mg}$ of sample into microwave vial and added $0.50 \mathrm{~mL}$ of hydrochloric acid and $0.50 \mathrm{~mL}$ of propionic acid and freeze $\left(-20^{\circ} \mathrm{C}\right)$ into the domestic freezer for 1 hour. Then the frozen vials were connected to the microwave accelerated unit (CEM, MARS 6, USA) and heated $160^{\circ} \mathrm{C}$ (ramping time $10 \mathrm{~min}$ ), and holding time was $15 \mathrm{~min}$. The vials were allowed to reach the room temperature and then hydrolysed solutions were completely sparged under nitrogen gas and reconstitute it around $\mathrm{pH}$ 8 using, $983 \mu \mathrm{L} 0.1 \mathrm{~N} \mathrm{NaOH}$ and $17 \mu \mathrm{L}$ of $7.5 \mathrm{~N}$ $\mathrm{NaOH}$. Then followed the below mentioned optimized derivatisation procedure.

In HPLC vial, $67.5 \mu \mathrm{L}$ of MPA, $33 \mu \mathrm{L}$ of OPA and $11.25 \mu \mathrm{L}$ of sample (or standard) mixed together and waited 1 min prior to adding $15 \mu \mathrm{L}$ of FMOC. Again, the vial was mixed and waited for $2 \mathrm{~min}$ and then added $0.1 \mathrm{~N} \mathrm{HCl} 7.5$ $\mu \mathrm{L}$ and injected to the HPLC. Each sample was run in triplicate. Limit of Detection (LoD) and Limit of Quantification (LoQ) for each amino acid was calculated based on the EURACHEM/CITAC method by injecting 6 replicates. 
G.D.T.M. Jayasinghe and B.K.K.K. Jinadasa

\section{HPLC Analysis}

Totally $10 \mu \mathrm{L}$ of samples were injected to Shimadzu-Nexera UHPLC (Shimadzu, Japan), equipped with a DGU-20As degausser unit, RF10AXL, SPD-M20A detectors, SIL-10A autoinjector and Shim-pack HR-ODS column $(150 \mathrm{x}$ $3.0 \mathrm{~mm}$ ID, $3 \mu \mathrm{m}$ ) eluted with $0.8 \mathrm{~mL} / \mathrm{min}$ binary gradient containing mobile phase (A) $20 \mathrm{mmol} / \mathrm{L}$ potassium phosphate buffer ( $\mathrm{pH}$ 6.5) in ultrapure water and (B) 45:40:15 Acetonitrile: Methanol: $\mathrm{H}_{2} \mathrm{O}$ respectively. The gradient program and summarized are given in Table 1 . The column oven temperature was at $40{ }^{\circ} \mathrm{C}$ and the excitation-emission wavelength condition was set as for FLD (Shimadzu, FLD-20 Axs) channel 1: 350-450 nm and channel 2: 266-305 nm

Table 1 HPLC program and summary

\begin{tabular}{|c|c|c|c|}
\hline Column & \multicolumn{3}{|c|}{ Shim-pack HR-ODS column ( 150 x 3.0 mm ID, $3 \mu \mathrm{m})$} \\
\hline Injection volume & \multicolumn{3}{|c|}{$10 \mu \mathrm{L}$} \\
\hline Flow rate & \multicolumn{3}{|l|}{$800 \mu \mathrm{L} / \mathrm{min}$} \\
\hline \multirow[t]{9}{*}{ Mobile phase composition } & \multicolumn{3}{|c|}{$\begin{array}{l}20 \mathrm{mmol} / \mathrm{L} \text { potassium phosphate buffer }(\mathrm{pH} \text { 6.5) in ultra-pur } \\
\text { water, (A) 45:40:15 Acetonitrile: Methanol: } \mathrm{H}_{2} \mathrm{O} \text { (B) }\end{array}$} \\
\hline & Total time (min) & $\mathrm{A} \%$ & $\mathrm{~B} \%$ \\
\hline & 0.1 & 85 & 15 \\
\hline & 4.0 & 85 & 15 \\
\hline & 5.5 & 80 & 20 \\
\hline & 7.5 & 65 & 35 \\
\hline & 11.5 & 64.5 & 34.5 \\
\hline & 13 & 100 & 0 \\
\hline & 18 & 85 & 15 \\
\hline
\end{tabular}

\section{Validation Study}

Individual 1, 10, 50 and $100 \mathrm{mg} / \mathrm{L}$ of amino acids were prepared as the serial dilution with $0.1 \mathrm{~N}$ $\mathrm{HCl}$. On the day of analysis, the above concentration was prepared. The calibration range and linearity were studied by injection of 5 concentrations of each amino acids standard of above and below the level of the range. The repeatability of standard and samples were checked using $100 \mathrm{mg} / \mathrm{L}$ standards injected in 6 times. The recovery was calculated by comparing in the triplicate value of each sample matrices and spiked sample preparing to the linearity range and treated as the same manner of samples.

\section{RESULTS AND DISCUSSION}

The microwave power and time optimized during the study, and maximum recovery for the spiked sample was received on $800 \mathrm{~W}$ power and 160 ${ }^{\circ} \mathrm{C}$ temperature reach on 10 min ramping time with 15 min holding time. In the harsh condition like the temperature $>160^{\circ} \mathrm{C}$, observed the low recovery of some more labile amino acids such as Thr and Sys. Lorenzo et al. (2013), reported the almost similar condition $\left(160-180{ }^{\circ} \mathrm{C}\right)$ for the bovine serum albumin samples, but they used a small sample volume than our study. Moreover, microwave assisted extraction technique used for the determination of free amino acids in plant and animal origin foods and found $10 \%$ higher extraction yield than traditional conventional techniques (Kovács et al. 1998). Liman and others (2016) reported, the microwave assisted extraction technique used for amino acids analysis in Tunisian animal feedstuff and they compared this method with the traditional hydrolysed method. The method performance showed very good separation to 18 amino acid with the low detection limits (Limam et al. 2016).

The chromatographic separation of 21 amino acid standards on FLD detector is shown in Figure 1. (Upper, Chanel 1: Ex:350 nm, Em:450 nm, Lower: Chanel 2: Ex:266 nm, Em:305 nm). 

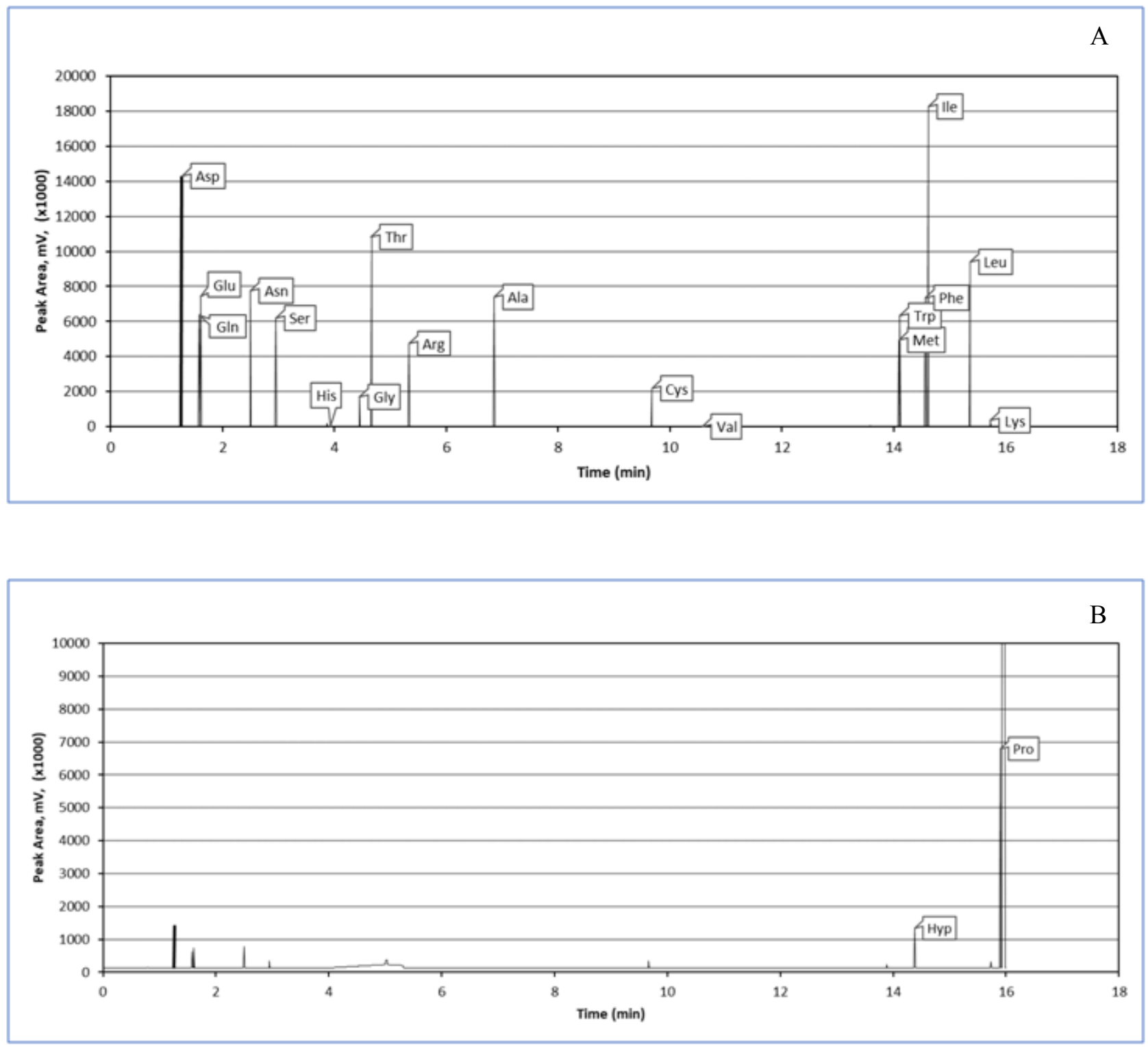

Fig 1 Amino acid chromatogram, HPLC-FLD, $100 \mathrm{mg} / \mathrm{L}, 10 \mu \mathrm{L}$ injection (upper: detector channel A, ex.350 nm, em. $450 \mathrm{~nm}$, lower: detector channel B, ex. $266 \mathrm{~nm}$, em. $305 \mathrm{~nm}$ )

The repeatability (use as a precision) of the method was observed and the retention time (Rt, min), standard deviation of retention time (Rt$\mathrm{SD}, \%)$, average peak area (x1000, mv), standard deviation of area (RSD, \%), concentration after injection of $100 \mathrm{mg} / \mathrm{L}(\mathrm{Con}-\mathrm{mg} / \mathrm{L})$ and standard deviation of concentration (Con.-SD, \%) are listed in Table 2. The best FLD detector response and linearity of each amino acids were given more than 0.99 (except proline and hydroxyproline, - 0.99) correlation coefficient in between 1-100 $\mathrm{mg} / \mathrm{L}$ (Figure 2). As Table 2, the method of recovery was very good for all 21 amino acids and ranges were complying with international standards recommended value (75125\%). The LoD and LoQ were calculated based on the standard deviation of the response and the slope of the linearity plot. The lowest LoQ was observed form Glu $(0.03 \mathrm{~g} / \mathrm{kg})$ while the highest LoQ was observed from Gln $(2.13 \mathrm{~g} / \mathrm{kg})$. 
G.D.T.M. Jayasinghe and B.K.K.K. Jinadasa

Table 2 Validation parameters of amino acids analysis

\begin{tabular}{rccccccccc}
\hline & Compound & Rt $(\mathrm{min})$ & $\begin{array}{c}\text { Rt-SD, } \\
\%\end{array}$ & Area & $\begin{array}{c}\text { Area, SD, } \\
\%\end{array}$ & $\begin{array}{c}\text { Con. } \\
(\mathrm{mg} / \mathrm{L})\end{array}$ & $\begin{array}{c}\text { Con.- } \\
\text { SD, } \%\end{array}$ & $\begin{array}{c}\text { LoD } \\
(\mathrm{g} / \mathrm{kg})\end{array}$ & $\begin{array}{c}\text { LoQ } \\
(\mathrm{g} / \mathrm{kg})\end{array}$ \\
\hline 1 & Asp & 1.27 & 0.01 & 14300661 & 2.08 & 97 & 1.82 & 0.36 & 1.08 \\
2 & Gln & 1.58 & 0.01 & 6373522 & 3.58 & 82 & 2.05 & 0.71 & 2.13 \\
3 & Glu & 1.61 & 0.01 & 7414772 & 1.98 & 97 & 1.68 & 0.01 & 0.03 \\
4 & Asn & 2.50 & 0.01 & 7752380 & 1.57 & 96 & 1.29 & 0.02 & 0.06 \\
5 & Ser & 2.95 & 0.06 & 6205232 & 2.00 & 96 & 1.70 & 0.38 & 1.15 \\
6 & His & 3.87 & 0.02 & 219216 & 2.27 & 95 & 2.12 & 0.18 & 0.54 \\
7 & Gly & 4.45 & 0.03 & 1705205 & 1.90 & 89 & 1.57 & 0.27 & 0.81 \\
8 & Thr & 4.66 & 0.01 & 10827093 & 1.98 & 89 & 1.74 & 0.26 & 0.78 \\
9 & Arg & 5.33 & 0.01 & 4746499 & 1.96 & 96 & 1.64 & 0.11 & 0.33 \\
10 & Ala & 6.85 & 0.01 & 7415506 & 1.84 & 95 & 1.74 & 0.13 & 0.39 \\
11 & Cys & 9.67 & 0.02 & 2163069 & 2.48 & 88 & 2.50 & 0.15 & 0.45 \\
12 & Tyr & 10.59 & 0.01 & 70016 & 2.76 & 98 & 2.35 & 0.11 & 0.33 \\
13 & Val & 13.58 & 0.01 & 85147 & 2.21 & 77 & 1.88 & 0.21 & 0.64 \\
14 & Met & 14.09 & 0.02 & 303475 & 3.68 & 78 & 3.13 & 0.04 & 0.12 \\
15 & Trp & 14.11 & 0.01 & 6343431 & 3.94 & 99 & 3.35 & 0.15 & 0.45 \\
16 & Hyp & 14.38 & 0.05 & 134181 & 1.21 & 101 & 3.22 & 0.17 & 0.51 \\
17 & Phe & 14.56 & 0.01 & 7348101 & 2.64 & 99 & 2.04 & 0.56 & 1.69 \\
18 & Ile & 14.61 & 0.01 & 18272117 & 1.21 & 101 & 2.49 & 0.08 & 0.25 \\
19 & Leu & 15.36 & 0.01 & 9417973 & 1.16 & 97 & 2.93 & 0.09 & 0.27 \\
20 & Lys & 15.73 & 0.03 & 335681 & 3.43 & 90 & 2.90 & 0.09 & 0.28 \\
21 & Pro & 15.90 & 0.04 & 67990 & 5.52 & 86 & 6.59 & 0.31 & 0.93 \\
\hline & & & & & & & &
\end{tabular}

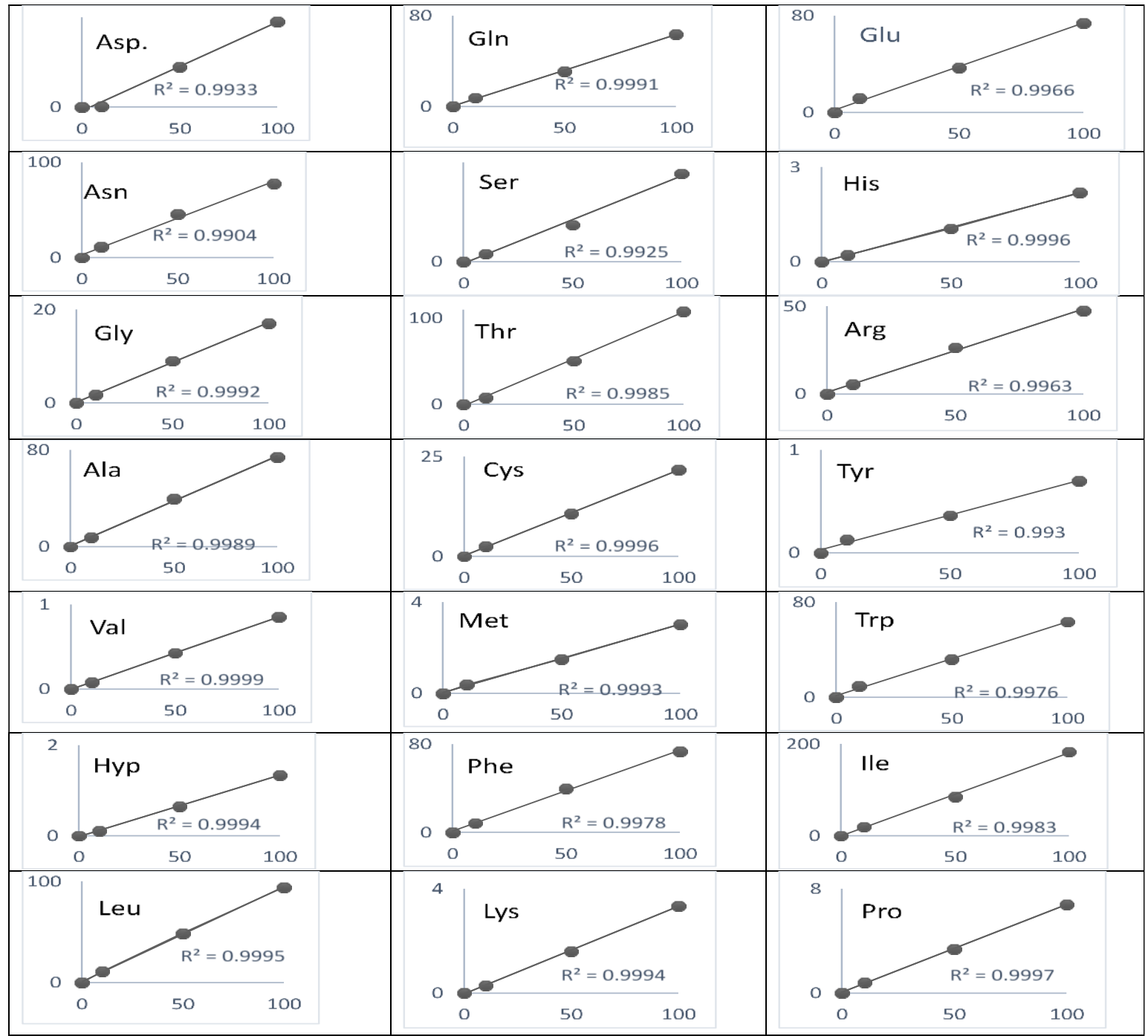

Fig 2 Calibration curve of pre-column derivatized 21 amino acids (Peak area x100,000) 


\section{Quantitative results of sample}

The quantitative results of the studied samples are given in Table 3. To confirmation of the results, Norvalin (Nva) and Sarcosine (Sar) used as an internal standard (IS) with all samples. The recovery of the IS was in-between $80-110 \%$. When quantification, we considered that the values below the LoQ as a not detected (ND).

Table 3 The hydrolysed amino acid concentration of fish (Lutjanus sp.), canned fish, fish feed \& seaweed (Sargassum sp.), the value $(\mathrm{mg} / \mathrm{kg})$

\begin{tabular}{rccccc}
\hline & Compound & Lutjanus sp. & Canned fish & Fish feed & Seaweed \\
\hline 1 & Asp & 4420 & 3018 & 20753 & 21270 \\
2 & Gln & 22454 & 20586 & 37 & 2337 \\
3 & Glu & ND & ND & 2794 & ND \\
4 & Asn & 65 & 72 & 5508 & ND \\
5 & Ser & 2548 & 1314 & 1344 & ND \\
6 & His & 1312 & 1476 & 1433 & 6614 \\
7 & Gly & 2662 & 3575 & 2128 & 4265 \\
8 & Thr & 1903 & 1678 & 70977 & 368 \\
9 & Arg & 5128 & 2283 & 2804 & 3617 \\
10 & Ala & 6316 & 6981 & 5088 & ND \\
11 & Cys & 3106 & 15042 & 2320 & ND \\
12 & Tyr & 495 & 2727 & 2166 & 4361 \\
13 & Val & 2095 & 4355 & 3936 & ND \\
14 & Met & 1595 & 1370 & 3077 & ND \\
15 & Trp & 3711 & 558 & 2011 & ND \\
16 & Hyp & 2852 & 2627 & 2087 & ND \\
17 & Phe & 3575 & 3350 & 76550 & ND \\
18 & Ile & 4525 & 1434 & 805 & 340 \\
19 & Leu & 9535 & 2193 & 26576 & 329 \\
20 & Lys & 1282 & 13806 & & 8801 \\
21 & Pro & 9789 & & & \\
\hline
\end{tabular}

\section{CONCLUSION}

New pre-column derivatizing method supported with microwave-assisted sample hydrolysing procedure was developed to quantify the amino acid profile of fish, fisheries products (canned fish, fish feed), and seaweed samples. The high sensitivity was achieved for 21 amino acids with FLD detector with the calibration range 1-100 $\mathrm{mg} / \mathrm{L}$ based on $10 \mu \mathrm{L}$ injections. The validated method can be used for hydrolysed amino acids detection of the fish, dried fish, fish feed and seaweed samples respectively.

\section{REFERENCES}

Afiuni-Zadeh, S., Guo, X., Azimi, G. and Lankmayr, E. 2011. Optimization and application of microwave-assisted acid hydrolysis for rapid quantification of protein oxidation markers using LC-MS. Talanta, 85, 1835-1841.

Bimal, M., Arabinda, M., Satabdi, G., Sankar, T. V., Kajal, C., Anandan, R., Baidyanath, P., Debajit, S., Suseela, M., Kurukkan, K. A., Bijay, B., Md, A., Dipesh, D., Vijayagopal, P., Sridhar, N., Akhtar, M. S., Neetu, S., Tandrima, M., Sudeshna, B., Prasenjit, P., Debajeet, D., Pushpita, D., Vijayan, K. K.,
Laxmanan, P. T. and Sharma, A. M. 2014. Amino acid compositions of 27 food fishes and their importance in clinical nutrition. Journal of Amino Acids 1, 1-7.

Chen, L., Wang, N. and Li, L. 2014. Development of microwave-assisted acid hydrolysis of proteins using a commercial microwave reactor and its combination with LC-MS for protein full- sequence analysis. Talanta 129, 290-295.

Choi, M. S., Rehman, S. U., Kim, I. S., Park, H.J., Song, M.-Y. and Yoo, H. H. 2017. Development of a mixed-mode chromatography with tandem mass spectrometry method for the quantitative analysis of 23 underivatized amino acids in human serum. Journal of Pharmaceutical and Biomedical Analysis 145, 52-58.

Dai, Z., Wu, Z., Jia, S. and Wu, G. 2014. Analysis of amino acid composition in proteins of animal tissues and foods as pre-column ophthaldialdehyde derivatives by HPLC with fluorescence detection. Journal of Chromatography B 964, 116-127.

Damm, M., Holzer, M., Radspieler, G., Marsche, G. and Kappe, C. O. 2010. Microwaveassisted high-throughput acid hydrolysis in silicon carbide microtiter platforms - A rapid 
G.D.T.M. Jayasinghe and B.K.K.K. Jinadasa

and low volume sample preparation technique for total amino acid analysis in proteins and peptides.Journal of Chromatography A 1217, 7826-7832.

Einarsson, S. 1985. Selective determination of secondary amino acids using pre-column derivatization with 9fluorenylmethylchloroformate and reversedphase high-performance liquid chromatography. Journal of Chromatography A 348, 213-220.

Fountoulakis, M. and Lahm, H.-W. 1998. Hydrolysis and amino acid composition analysis of proteins. Journal of Chromatography A 826, 109-134.

Jajić, I., Krstović, S., Glamočić, D., Jakšić, S. and Abramović, B. 2013. Validation of an HPLC method for the determination of amino acids in the feed. Journal of the Serbian Chemical Society 78 (6) 839-850 (2013).

Kovács, Á., Ganzler, K. and Simon-Sarkadi, L. 1998. Microwave-assisted extraction of free amino acids from foods. Zeitschrift für Lebensmitteluntersuchung und-Forschung A 207, 26-30.

Li, X., Rezaei, R., Li, P. and Wu, G. 2011. The composition of amino acids in feed ingredients for animal diets. Amino Acids 40, 1159-1168.

Limam, I., Medimagh, R. and Hellal, F. 2016. Determination of amino acids in Tunisian animal feedstuffs by HPLC-FLD. Eurasian Journal of Analytical Chemistry 11, 211-224.

Lorenzo, M. P., Navarrete, A., Balderas, C. and Garcia, A. 2013. Optimization and validation of a CE-LIF method for amino acid determination in biological samples. Journal of Pharmaceutical and Biomedical Analysis 73, 116-124.

Min, S. C., Shaheed, U. R., In, S. K., Hi-Joon, P., Mi-Yeon, S. and Hye, H. Y. 2017. Development of a mixed-mode chromatography with tandem mass spectrometry method for the quantitative analysis of 23 underivatized amino acids in human serum. Journal of Pharmaceutical and Biomedical Analysis 145, 52-58.

Mudiam, M. K. R. and Ratnasekhar, C. 2013. Ultra sound assisted one step rapid derivatization and dispersive liquid-liquid microextraction followed by gas chromatography-mass spectrometric determination of amino acids in complex matrices. Journal of Chromatography A 1291, $10-18$.

Nunes, A. J. P., Sá, M. V. C., Browdy, C. L. and Vazquez-Anon, M. 2014. Practical supplementation of shrimp and fish feeds with crystalline amino acids. Aquaculture 431, 20 27.

Wang, N. and Li, L. 2010. Reproducible microwave-assisted acid hydrolysis of proteins using a household microwave oven and Its combination with LC-ESI MS/MS for mapping protein sequences and modifications. Journal of the American Society for Mass Spectrometry 21, 15731587.

Yanting, S., Chang, X., Hiroshi, K., Yiyi, L. and Makoto, T. 2018. Recent trends in analytical methods for the determination of amino acids in biological samples. Journal of Pharmaceutical and Biomedical Analysis 147, 35-49.

Yu, H. M., Chen, S. T., Chiou, S. H. and Wang, K. T. 1988. Determination of amino acids on Merrifield resin by microwave hydrolysis. Journal of Chromatography A 456, 357-362. 